\title{
Corpus
}

CORPUS Archivos virtuales de la alteridad americana

Vol. 11, No. $2 \mid 2021$

Julio / Diciembre 2021

\section{La Africana: canciones de una comparsa de falsos negros del carnaval porteño (1869-1879)}

La Africana: songs of a carnival ensemble of whites performing as blacks in the Buenos Aires carnival (1869-1879)

\section{Ezequiel Adamovsky}

\section{(2) OpenEdition}

\section{Journals}

Electronic version

URL: https://journals.openedition.org/corpusarchivos/5125

DOI: 10.4000/corpusarchivos.5125

ISSN: 1853-8037

Publisher

Diego Escolar

Electronic reference

Ezequiel Adamovsky, «La Africana: canciones de una comparsa de falsos negros del carnaval porteño (1869-1879)», Corpus [En línea], Vol. 11, №. 2 | 2021, Publicado el 15 diciembre 2021, consultado el 26 diciembre 2021. URL: http://journals.openedition.org/corpusarchivos/5125 ; DOI: https://doi.org/ 10.4000/corpusarchivos.5125

This text was automatically generated on 26 December 2021.

Licencia Creative Commons: Atribución-NoComercial 2.5 Argentina (CC BY-NC 2.5 AR) 


\title{
La Africana: canciones de una comparsa de falsos negros del carnaval porteño (1869-1879)
}

La Africana: songs of a carnival ensemble of whites performing as blacks in the Buenos Aires carnival (1869-1879)

\author{
Ezequiel Adamovsky
}

\section{EDITOR'S NOTE}

Fecha de recepción del original: 27/08/2021

Fecha de aceptación para publicación: 29/10/2021

1 A partir de 1865, y hasta los primeros años del siglo XX, el carnaval de Buenos Aires fue testigo de un fenómeno sorprendente. Por los corsos de la ciudad desfiló una cantidad enorme de comparsas integradas por blancos que de diversas maneras buscaron asociarse a lo africano, sea a través de los nombres identificatorios que eligieron, imitando el habla o el canto de los negros, bailando o ejecutando el candombe (o algún remedo de él), vistiendo ropajes que se pretendían típicos de los esclavizados coloniales, de tribus del África o incluso de afroestadounidenses y, en ocasiones (no siempre), tiznándose la cara o usando caretas negras. ${ }^{1}$ Por entonces compartieron el espacio de la celebración con una cantidad igualmente notable de comparsas de afrodescendientes reales que también pusieron en escena signos de su origen étnico, lo mismo que las muchas que animaron diversas colectividades de inmigrantes. También hubo comparsas de blancos que se caracterizaban como indios y otras que se disfrazaban de gauchos. Sin lugar a dudas, el carnaval fue una arena para la negociación de las diferencias étnico-raciales, en la que era una de las urbes más multiétnicas del planeta (Martin, 2008; De Lucía, 1999; Puccia, 2000; Chamosa, 2003). En otro trabajo documenté la existencia de más de 200 comparsas de negros, o de blancos que los imitaban -la mayoría eran seguramente las últimas- en el carnaval porteño de fines 
del siglo XIX. El pico del fenómeno se dio en el año 1879, en el que desfilaron más de sesenta simultáneamente (Adamovsky, en prensa 3). Aunque se han registrado agrupaciones carnavalescas que imitan a los negros en diversos países del continente americano -en Montevideo, por caso, tuvieron una importancia similar a la de este lado del Plata (Andrews 2007) - la cantidad que hubo en Buenos Aires resulta verdaderamente notable.

2 A pesar de su importancia, las comparsas de falsos negros han merecido escasa atención. ${ }^{2}$ Los estudios sobre el carnaval o la historia de los afroporteños suelen mencionarlas, pero solo cuatro trabajos avanzaron en un análisis de sus actuaciones, sobre la base de una documentación sin embargo limitada (Sánchez et al., 2006; Geler, 2011; Chasteen, 2000; Martín, 2015). Este trabajo apunta a contribuir a una indagación en forma sobre el fenómeno de las comparsas de falsos negros. En otro sitio recopilé las canciones y analicé la trayectoria y actuaciones de la primera y más conocida, Los Negros (Adamovsky, en prensa 1). En esta ocasión presento la recopilación de las canciones de otra comparsa de la misma época, también de renombre, llamada La Africana. Sobre la base de un trabajo exhaustivo de fuentes primarias, este trabajo presenta la transcripción de veintinueve canciones, que es por lejos el corpus más rico que haya dejado una comparsa de falsos negros. Junto con ellas, se ofrece una descripción general de la comparsa y de sus actuaciones y se adelantan algunas hipótesis preliminares sobre sus posibles conexiones con otros usos de lo negro por parte de blancos que existían en la misma época en otros sitios. No es este el lugar, sin embargo, para avanzar en una interpretación de los sentidos de negritud que pusieron en juego en los carnavales o sobre su relación con las jerarquías raciales de la época, algo que requeriría una evaluación de conjunto de todo el fenómeno de las comparsas de falsos negros.

\section{La comparsa: características y composición}

3 La Africana fue el nombre con que se conoció a la comparsa de la Sociedad Dramática Musical La Africana. Salió por primera vez en el carnaval de 1869 y siguió haciéndolo hasta $1879 .{ }^{3}$ Posiblemente -no es seguro- el nombre fuera en homenaje a la ópera homónima de Meyerbeer, que aún no se había estrenado en Buenos Aires (lo haría en junio de 1870) pero era esperada con ansiedad desde antes por los jóvenes melómanos porteños. ${ }^{4}$ Estaba compuesta "en su totalidad por jóvenes distinguidos", ${ }^{5}$ entre los que sobresalían Julio P. Celecia/Celesia, Alberto Medrano, Tomás Guesalaga/Guezalaga (los tres oficiaron en diferentes años como sus directores), Nicasio Duarte, Alberto Diana y Adolfo Lamarque, quien luego se destacaría como escritor y abogado. Un conocido dramaturgo en años posteriores, Martín Coronado, escribió para ellos una canción. En 1870 y 1871 editaron un periódico semanal propio, titulado La Africana, en el que reseñaban las tertulias y la vida social de la juventud acomodada y publicaban poesías, notas sobre vida estudiantil y sobre temas galantes. Eran buenos amigos de Los Negros, la primera comparsa de falsos negros, también formada por jóvenes de clase acomodada, con la que en 1870 marcharon juntas. ${ }^{6}$ Con las comparsas integradas por personas de condición modesta parecen haber tenido una relación más distante. Se notó en 1879, cuando el corso más popular de la calle del Buen Orden le otorgó un premio, a cambio del cual recibieron un desplante: La Africana se negó a retirarlo argumentando que "renunciaba a cualquier distinción de ese género". ${ }^{7}$ 
Comparada con otras de la época, era una comparsa de tamaño mediano-grande: declaraba 100 socios en 1871 y un año antes de su última actuación sacaba a las calles unos 80 integrantes. ${ }^{8}$ Visitaban casas de familias conocidas, actuaban en los corsos porteños y en bailes de carnaval en teatros y locales y sabemos que lo hicieron también en otras ciudades, entre ellas Quilmes, San Fernando, Morón y Mercedes. ${ }^{9}$ Marchaban encabezados por un estandarte y cantando canciones con el acompañamiento de "una bien organizada orquesta"; no sabemos los instrumentos que la componían, fuera de "pitos", "cornetas" y una banda de catorce tambores comprados especialmente en Europa. ${ }^{10}$ De su vestimenta no sabemos nada, salvo que la describían como de "elegantes trajes" (lo que sugiere que no remedaba la vestimenta de esclavizados que usaban otras comparsas de su tipo). ${ }^{11}$ Los documentos de la época no mencionan que se tiznaran la cara o usaran caretas negras, ni tampoco que realizasen alguna coreografía, aunque ello no debería descartar que acaso lo hiciesen.

Por su composición social, tanto La Africana como Los Negros se distinguen de otras comparsas de falsos negros de años posteriores integradas por gente de condición más modesta. Los datos disponibles hasta el momento sugieren que sus estilos y estéticas también eran significativamente diferentes (Adamovsky, en prensa 4).

\section{Las canciones}

6 La Africana es, de lejos, la comparsa de falsos negros de la que mayor cantidad de letras de canciones se han conservado: tras un intenso trabajo de archivo hemos podido recuperar en total veintinueve. Los textos que aquí transcribimos tienen procedencias diversas. Algunas canciones aparecieron en el periódico de la propia comparsa. Otras, en libros o revistas dedicadas exclusivamente a compilar letras de las agrupaciones que actuaban algún año. Otras proceden de revistas de interés general y algunas aparecieron incluidas en libros de poemas propios que luego editaron algunos de sus miembros. Todos estos materiales se hallan dispersos. El periódico La Africana se conserva en la hemeroteca de la Universidad Nacional de La Plata. Una buena cantidad de canciones proviene de un pliego suelto que editó la propia comparsa, conservado en el Instituto de Investigación Musicológica "Carlos Vega" de la Universidad Católica Argentina. El resto de las publicaciones se encuentran en los acervos de la hemeroteca, el tesoro y la sala general de la Biblioteca Nacional. La única partitura hallada se conserva en el Instituto de Investigaciones en Etnomusicología de la ciudad de Buenos Aires. Las letras se transcriben aquí tal como aparecieron en sus fuentes originales, sin modificar su ortografía. Cuando aparecieron en más de un sitio o con ligeras variaciones se lo indica en el texto. La información de cada canción incluye también, allí donde fue posible saberlo, las autorías y ritmos y datos adicionales de su uso por parte de otras comparsas en Buenos Aires, Córdoba y Montevideo, lo que nos ofrece indicios sobre conexiones y difusión.

7 No contamos con las partituras (salvo de una que tomaron de otra comparsa), pero las designaciones de varias de ellas nos permiten conocer al menos el género musical: hay tres habaneras $(11,13,21)$, dos mazurcas $(3,12)$, un tango $(16)$, una romanza $(17)$, un chotis (20), un vals $(23)$ y dos marchas $(18,24)$. Una de las letras (5) menciona también el gusto por la mazurca, la polka y el vals, otra (27) coincide en lo que refiere a las dos últimas y otra (13), por el tango. 
8 No es este el lugar para avanzar en un análisis del sentido de las performances de La Africana, lo que requeriría un conocimiento cabal del contexto carnavalesco de esos años que aún no tenemos. Las comparsas de falsos negros que actuaron a fines del siglo XIX posiblemente superaran el centenar y hubo otras tantas animadas por la colectividad afroporteña o mixtas (Adamovsky, en prensa 3). Todo indica que había gran heterogeneidad en los estilos de cada tipo. En lo que respecta a las de falsos negros, las estéticas, la procedencia social de sus miembros y el contenido de las canciones podían ser enormemente variables, por lo que no conviene avanzar en el tipo de generalizaciones que se hallan en los trabajos disponibles. Tampoco tenemos buena información sobre las relaciones entre las comparsas de este tipo y las de afroporteños con las que compartían el espacio de los corsos. No sería posible analizar cabalmente las performances de La Africana sin conocer mejor el contexto en el que actuaban, lo que quedará entonces para futuros trabajos.

Con esas limitaciones, es posible avanzar sin embargo en algunas observaciones preliminares. Está claro que las actuaciones de La Africana involucraban la utilización de signos culturales vinculados a los afrodescendientes: se trataba de blancos personificando a negros. Pareciera que no en la vestimenta y no sabemos si se tiznaban el rostro, pero sí en los demás elementos. La prominencia de la percusión en la orquesta sugiere que su sonoridad buscaba evocar lo africano. Lo mismo vale para la elección de géneros como el tango (en esos años muy asociado a los negros) y la habanera, de origen afrocubano, aunque ya por entonces fuese un género transnacional. En la letra de las canciones se hace especialmente evidente. En casi todas ellas son personajes negros (varones) quienes hablan en primera persona. Tres de ellas $(11,13,14)$, además, están escritas imitando el estilo de habla "bozal" de los afrodescendientes y una más emplea algún modismo que lo parece (8). Incluso fuera de la época de carnaval, los integrantes de la comparsa se identificaban como "africanos" o "negritos", decían hacer "cosas de negros" y uno de los columnistas estables de su periódico se apodaba "Zambo", el vocablo colonial para designar a mestizos de negro y amerindio. ${ }^{12}$

10 Algunos académicos han planteado la posibilidad de trazar comparaciones entre las comparsas de blancos tiznados que florecieron en el último tercio del siglo XIX y el género teatral de blackface minstrelsy anglosajón (Geler, 2011; Martín, 2008). La comparación con un fenómeno mucho mejor conocido sin dudas puede ayudar a echar luz sobre la cuestión. Pero otros investigadores dieron un paso más. Teniendo en cuenta que en julio de 1869 debutaron en un teatro porteño los Christy's Minstrels, compañía estadounidense que habría puesto a disposición del público los repertorios de denigración de los negros propios de esos espectáculos, algunos trabajos han sostenido que el blackface minstrelsy tuvo una "clara influencia" en el carnaval porteño (Chasteen, 2000) o incluso que una comparsa como Los Negros "emulaba a los minstrels estadounidenses" (Cirio, 2015). Esa idea fue retomada por uno de los estudios transnacionales sobre minstrelsy, en el que también se puede leer que las comparsas porteñas "se inspiraron en la estética del blackface minstrel" (Thelwell, 2020). Desde este punto de vista, las actuaciones de Los Negros o La Africana tendrían una función similar a la de sus contrapartes anglosajonas - tramitar las tensiones raciales entre blancos y negros- y deben interpretarse fundamentalmente como una expresión de racismo.

11 En otro trabajo me ocupé de analizar detalladamente las actuaciones de los Christy's Minstrels de ese año y otras posteriores, junto con otros antecedentes, especialmente el de Albert Phillips, un artista norteamericano que montó espectáculos de minstrelsy en 
Buenos Aires en 1868. En mi investigación estudié los vestuarios, instrumentos musicales, danzas y sketches cómicos de todos esos shows, junto con las letras y partituras de más de treinta de las canciones que sabemos que interpretaron. Además, indagué en la recepción que tuvieron entre el público local (Adamovsky, en prensa 2). Luego comparé todo ello con las actuaciones que Los Negros realizaron en los carnavales luego de 1865, para llegar a la conclusión de que no hay motivos empíricos que permitan afirmar que la primera comparsa de falsos negros porteña se hubiese inspirado en ese tipo de espectáculos. Casi nada en lo que hacían se parecía a lo que hacían los artistas estadounidenses: los vestuarios, las coreografías, los instrumentos musicales utilizados, los géneros de las canciones y los contenidos de las letras: todo era muy diferente. Por lo demás, contamos con el testimonio de época del propio periódico Los Negros, que reseñó el espectáculo de los Christy's Minstrels de un modo que dejaba perfectamente en claro que les resultaba algo exótico, para consumo de la colectividad anglosajona, y que no encontraban punto de comparación con lo que la comparsa hacía aquí. De hecho, sabemos que el público que asistió a los shows de esa compañía fue abrumadoramente extranjero, con pocos porteños interesados. Y el arte del minstrelsy no dejó continuadores en las tradiciones teatrales locales y siguió siendo en años posteriores del interés exclusivo de los expatriados (Adamovsky, en prensa 2).

En la medida en que La Africana también se formó antes de la visita de los bufos estadounidenses y que sus actuaciones eran bastante similares a las de Los Negros, las conclusiones esbozadas pueden hacerse extensivas a nuestra comparsa, aunque con algún matiz. Por falta de información no podemos comparar vestimenta o coreografía, pero sí el aspecto musical. La línea de bajo propia de la habanera y, por supuesto el tango, estaban totalmente ausentes en las composiciones de los Christy's Minstrels, que eran sobre todo baladas, jigs y polkas. Los instrumentos que usaba La Africana tambores, pitos, cornetas- no figuraban en los shows de minstrelsy que se vieron en Buenos Aires, los que sí utilizaron en cambio otros, como el banjo y los huesos, que no hemos registrado en ninguna comparsa porteña.

En las letras de las canciones, los espectáculos de minstrelsy presentaban personajes negros que hablaban en primera persona y a veces imitando estilos de locución peculiares de los afroestadounidenses. En ese punto podrían encontrarse similitudes. Pero, fuera de eso eran bastante diferentes. En las de nuestra comparsa hay ciertamente estereotipos sobre los negros, pero no se hallan letras con agresividad hacia los afroporteños, ni la voluntad deliberada de construir estereotipos negativos o grotescos respecto de ellos, como sí las había en las de los Christy's Minstrels, que eran satíricas y se mofaban del aspecto físico de los negros o de su poca inteligencia. En las letras de La Africana, como en las de Los Negros, predominan las canciones de amor. Son en este caso siempre varones negros los que declaran su amor por alguna mujer y suplican por su atención. En la mayoría de los casos la destinataria de las súplicas es una muchacha blanca $(3,7,8,9,10,11,12,13,14,15,16,17,20,27)$ aunque en otras es una negra $(4,6,25)$. Pero, a diferencia de las de Los Negros, que eran puramente románticas, en las de La Africana sí hay algunos elementos que vinculan el cuerpo afrodescendiente con lo sensual. Dos de las tres mujeres negras que son objeto de solicitaciones aparecen descritas como "fogosas" (4) o de "labios de fuego" (6), un tipo de alusión que nunca se hace presente cuando la muchacha deseada es blanca (para ella las descripciones giran solo en torno de la hermosura, el candor o incluso la pureza). Por su parte, los personajes negros en alguna ocasión también se autorretratan como "fogosos", "ardientes" o destacan su atractivo $(5,7,15,16,20,23)$. Pero se trata en 
general de una sensualidad muy moderada, matizada además por otras letras en las que los negros son "emblema de la constancia y el puro amor" (16) o expresan un "sentimiento puro" (19). Solo una, la única de todas de estilo picaresco (2), sexualiza verdaderamente el cuerpo de un varón afrodescendiente, bien que de manera oblicua, por vía de una mención a su "morrongo" (gato) tras la cual no cuesta suponer la alusión a su órgano sexual. Pero es importante insistir en que se trata en todos los casos de atributos deseables desde el punto de vista del autor de las canciones: no hay letras que asignen a los negros rasgos despreciables y puramente negativos, como la estupidez, la fealdad o los defectos físicos, como sí las hallamos en los espectáculos de minstrelsy (Lott, 2013).

14 Sí hay cinco de las canciones en las que el coro - que también da voz a negros/as- se burla o critica la ocurrencia del hablante principal negro de pretender a una blanca, lo que aparece como algo risible, presuntuoso o fuera de lugar $(7,9,14,15,23)$. Pero es interesante constatar que varias canciones reclaman de manera explícita el derecho de los negros de cortejar a las blancas en una sociedad regida por el principio de la "igualdad" $(3,10,12,14,16,15$, esta última lo hace literalmente en respuesta a las críticas del coro). Una de ellas hace un verdadero elogio de la perspectiva de la mezcla entre negros y blancos y afirmaba que "es mentira el color" (20). De hecho, el reclamo de igualdad y la crítica a la discriminación racial es un tópico bastante presente en las canciones de La Africana $(1,3,10,12,14,15,25)$, lo que las hace bastante diferentes a las del minstrelsy, que, con mucha frecuencia, por el contrario, idealizaban la vida supuestamente simple y feliz de los afroestadounidenses en las plantaciones de algodón o de maíz. Más aún, una de las canciones de La Africana sitúa la nostalgia por una felicidad pasada en el continente africano y dice explícitamente que la libertad allí perdida ya no había sido posible en América, "en la jaula del blanco" (25).

15 En casi todas las letras, la condición de negro aparece asociada al amor y a la pasión. El negro dirige un ruego constante al objeto de su deseo amatorio, las muchachas, en general -pero no siempre- blancas. Se las invoca permanentemente como "amitas" $(3,7,11,14,15,16,22,27)$, lo que coloca así el hablante negro en condición servil. Quien lleva la voz cantante sufre al ser rechazado o al no encontrar la atención que desea. En cuatro de ellas $(7,9,17,21)$, la condición de "esclavo" se utiliza como metáfora para referir a ese deseo que lo somete a la voluntad de la mujer, que es quien tiene el poder de permitirle saciarlo. En dos de ellas el negro manifiesta incluso su esclavitud como deseo: desea hacerse esclavo de la mujer ("Quiérame pues, niña blanca/Que yo adorarla sabré/... De esclavo la serviré"). En otra, titulada justamente "El esclavo" (17), el sufriente negro dice que un beso de la muchacha ansiada lo liberaría del peso de sus cadenas, que no son otras que el "yugo" de la pasión. Aquí la analogía entre la condición del esclavo y el sometimiento al deseo por una mujer, con las penurias que ello implica cuando no logra consumarse, se vuelve explícita. Finalmente, una canción plantea que la condición de negro no es de nacimiento: quien canta dice que, si tiene el rostro negro, es "Porque lo ha quemado/ El fuego de inmenso amor" (7). Todas estas imágenes - la del varón como "esclavo" de la mujer a la que desea, la de la amada como "amita" y la del color negro como efecto del fuego del amor- están también presentes en las letras de la comparsa Los Negros.

Junto con el uso del personaje del negro/esclavo para tematizar las expectativas amorosas, lo negro también aparece asociado en algunas canciones $(19,21,23,26)$ con la alegría, el goce, el placer y el tiempo de libertad que habilitaba el carnaval, que eran 
también cosas que exaltaban otras canciones de la comparsa en las que no había alusiones étnicas $(18,24,28,29)$ y que eran, además, tema de las comparsas de cualquier tipo que actuaban por entonces. También en las canciones de Los Negros habíamos hallado este elemento: la personificación del negro, su alegría desembozada, habilitaba una evasión respecto de las rigideces propias del mundo social distinguido, en el que las emociones, más que liberarse, debían contenerse. Precisamente, la evasión que también permitían los tres días de carnaval.

17 En el trabajo comparativo con Los Negros, sostuve que, si alguna influencia transnacional había que buscar, no era la del blackface anglosajón sino las de otras prácticas disponibles de escenificación de lo negro por parte de blancos, en particular las que utilizaba la zarzuela española, de gran presencia en los tablados porteños de entonces, que a su vez retomaba modos de representación de lo negro de Cuba y del Siglo de Oro español, que tenían una raíz previa y usos diferentes de los del teatro anglosajón (Lane, 2005; Lipski, 2005). A los indicios que allí aporté, el repertorio de La Africana suma otros. Apuntan en ese sentido la presencia de las habaneras y sobre todo del "tango" -seguramente un tango hispano-cubano como los que utilizaban otras comparsas de la época (Vega, 2016) -, géneros traídos por las compañías de zarzuela. La línea "vente conmigo, chinita", de la canción número 13, se encuentra además en la popularísima habanera "La Paloma", compuesta hacia 1863 por Sebastián Yradier, quien solía escribir música para zarzuelas en España. Uno de los Brindis de La Africana (29) es de letra similar a otro de la zarzuela La almoneda del diablo (1862) de Rafael García Liern, que se había estrenado en Buenos Aires poco antes y que incluía bailes de falsos negros (Gesualdo, 1961, p. 863). ${ }^{13}$ Es sugestivo asimismo el uso picaresco de la metáfora del "morrongo" (2) que reencontremos en piezas teatrales españolas -cierto que posteriores-como el famoso "Tango del morrongo".

18 Comoquiera que hayan sido las posibles influencias transnacionales, en el caso de La Africana la más evidente fue local: la de la comparsa Los Negros (1865-1870), muy similar a ella en varios sentidos y de la que tomaron una o dos canciones (3 y 8) y posiblemente el estilo de vestuario. Como sostuve en otro trabajo, no es evidente que Los Negros se inspiraran en el candombe afroporteño, una práctica que sabemos que percibían como algo más bien lejano y ajeno a lo que hacían (Adamovsky, en prensa 1). No parecería que Los Africanos hubiesen tomado tampoco sus prácticas directa y principalmente de las de los afroporteños, algo que sí resulta más factible en el caso de otras comparsas posteriores, de las que sabemos que utilizaban vestimentas $\mathrm{y}$ coreografías más alusivas. En cuanto a la posible influencia de comparsas de falsos negros de otras ciudades cercanas - las hubo numerosas en Montevideo y también en varias de la Argentina-, todo indica que las de Buenos Aires tuvieron precedencia y acaso sirvieron de inspiración a las demás. De hecho, cuanto en 1867 Los Negros desfilaron en Montevideo, fue aparentemente la primera comparsa de blancos tiznados que se veía allí (Goldman, 2008, pp. 115-116) y no conozco evidencias de otras más tempranas en localidades argentinas.

19 Queda para futuros trabajos, entonces, la tarea de analizar los usos y sentidos de la personificación de lo negro en la comparsa La Africana, lo que sería indispensable para interpretar más en profundidad sus canciones, la relación que sus prácticas establecían con las jerarquías raciales de la época y el modo en el que interactuaban con el racismo entonces imperante. 


\section{Registros}

1.- "¡Africanos, libertaos!" (1870): Letra de Juan O'Rork. Descrita como "himno" (La Africana, no. 1, 20/11/1870, p. 2).

CORO

Ya suena el clarín de alarma;

la República es jigante (sic);

nuestro esfuerzo es arrogante:

¡Patria, Muerte o Libertad!

Aquí desde el desierto de Sahara,

Centro de los esclavos hasta ahora;

una madre feliz sonríe y llora

y esta madre se llama LIBERTAD

Temblado oh Reyes, maldecida raza,

que no habrá ya oprimidos ni opresores,

los castillos de bárbaros señores,

Han de ser IGUALDAD FRATERNIDAD!

CORO: Ya suena etc.

Africanos! ¿qué son esas coronas

por la mano infernal abrillantadas?...

Quebraremos espadas con espadas,

y sangre, sangre correrá no más.

Imitemos, por Dios, el Santo ejemplo

de aquella gran República del Norte,

el Dios de las batallas nos conforte,

y ya libres seremos por jamás.

CORO: Ya suena etc.

Miramos esa tierra de Occidente

que hizo temblar el mundo con sus lanzas

queremos libertad: habrá matanzas

cual fueron en América del Sud!

Bendita la República Argentina

que por siempre dio en tierra con tiranos,

y nosotros, que somos AFRICANOS,

queremos libertad o el ataúd!

CORO: Ya suena etc.

Está la Francia, que nos dice ALERTA!

La corona cayó de Bonaparte,

alcemos el repúblico estandarte 
2.- "El Gato" (1871). Canción cantada en el carnaval de 1871 (La Africana, no. 12, 19/2/1871, p. 2. También en El carnaval de 1871, colección de canciones de las comparsas que saldrán este año, Buenos Aires, Imprenta de la Discusión, 1871 y Almanaque Carnavalesco, por Orion, Buenos Aires, La Tribuna, 1871, p. 98).

y el Dios de los ejércitos dirá:

Africanos, romped esas cadenas,

harto habéis hecho en deteneros tanto,

ya, como libres, entonad el canto:

¡LIBERTAD, IGUALDAD, FRATERNIDAD!

Tiene un gato el moreno,

Jesús qué gato,

Que maúlla en invierno

Calla en verano

Por que se duelan

Es que en invierno tiene

Dolor de muelas.

Pobre morrongo mío,

Morrongo ven,

Que las niñas Morrongo

Te quieren ver.

Que solo ellas

Verás cómo te alivian

Dolor de muelas.

Mi niña si escucha

Que el pobre gato

Con ojos de tristeza

Maúlla, miao,

Por Dios se duelan

Porque tiene el morrongo

Dolor de muelas.

Sabe usted niña hermosa

Lo que se sufre,

Que no hay nada en el mundo,

Con que se cure

¿Me desespera

De mi pobre morrongo

Dolor de muelas.

3.- "El suspiro del negro" (1871). Canción cantada en el carnaval de 1871 (El carnaval de 1871, colección de canciones de las comparsas que saldrán este año, Buenos Aires, Imprenta de 
la Discusión, 1871). Es una mazurca compuesta por Miguel Rojas en 1865 para la comparsa Los Negros (La Africana, no. 13, 26/2/1871, p. 4. En otra edición del periódico se informa que la cantó un tal Nikilsom y sintetizan su temática como la del suspiro "desgarrador que lanza el esclavo al verse sujeto con la cadena de bárbaro señor"; La Africana, no. $13,26 / 2 / 1871$, p. 1). El periódico Los negros menciona una del mismo nombre como canción propia de esa comparsa: Los Negros, 25/7/1869, p. 1. La partitura se conserva en el Instituto de Investigaciones en Etnomusicología (Buenos Aires).

Cuando al espejo me miro amita

y me contemplo, tan negro y tan...

Cierro los ojos, a mi pobre alma

Crudo y amargo se escapa un ay!

CORO

Es porque sabes

que el ser moreno

es de la tierra

tremendo mal.

Pues son las blancas

muy vanidosas

sin ver que negros

y blancos somos

hijos de Adán.

Cuando gozoso por los paseos

ando y encuentro blanca beldad

al ver que nunca quiere ella amarme

se escapa a mi alma, muy triste, un ay!

CORO: Es porque sabes... etc

Cuando una blanca contemplo y veo

que cruel sonríe viendo mi faz,

fiero maldigo mi triste suerte

y lanzo agudo, tremendo un ay!

CORO: Es porque sabes... etc

Nunca en mis labios se vio la risa

ni hubo en mi pecho placer jamás

solo sí, siempre, para quejarme

de mi destino, tuve un crudo ay!

CORO: Es porque sabes... etc

Mas hoy! Qué gusto! dentro del alma

la dicha siento, bullendo está

Porque siquiera lanzar hoy puedo

de venturanza tremendo ay! 
CORO:

Es porque solo

en este día

a las morenas

las blancas dan

una mirada

dulce, halagüeña

y que hijos todos

también recuerdan

somos de Adán.

No sé negra mía

que siento por ti

allá en mis adentros

me siento morir.

Que no sé qué tengo

desde que te vi;

tu mirar de fuego

tu dulce reír

Tan profundamente

se han grabado en mi

Que... no sé qué tengo

desde que te vi.

Tus tiernas mejillas

de nieve y carmín

tus labios hermosos

cual rosa de abril.

Me has enloquecido

desde que te vi

tu esbelta figura

airosa y gentil

inspiran al hombre

4.- "No sé qué tengo" (1871). Canción cantada en el carnaval de 1871 (La Africana, no. 13, 26/2/1871, p. 4. También en El carnaval de 1871, colección de canciones de las comparsas que saldrán este año, Buenos Aires, Imprenta de la Discusión, 1871 y en Almanaque Carnavalesco, por Orion, Buenos Aires, La Tribuna, 1871, pp. 101-103).

Compasión, compasión de los negros

que en endechas cantan sus amores

Compasión, bellas niñas, ya es tiempo

que nos deis con amor ricas flores. 

Letra de Adolfo La
20-21/2/1869, p. 1)

loco frenesí.

Y... no sé qué tengo

desde que te vi.

Tus brazos de nieve

tu cuello es marfil

tu seno un tesoro

de riquezas mil

por eso estoy loco

desde que te vi

olvida este mundo

pronuncia ese sí

y un lazo amoroso,

nos hará feliz;

que no sé qué tengo

desde que te vi

No quieren ambicionar

Sino agradar a las niñas

Del presente carnaval.

Si las porteñas hermosas

Desean nuestra amistad

Deben tratarnos a todos

Con gran familiaridad.

Nadie lo debe extrañar

Nos mire con suavidad

Para sentir en el alma

En el pecho grabaremos

Con emoción celestial

Y como son tan amables

5.- "Canción para la Sociedad Dramática-Musical La Africana/ Tercera canción" (1869):

Los negros de la "Africana"

Si es que somos muy fogosos

Porque venimos del África

Donde hay un sol tropical.

Nos basta que una pollita

Los temblores de un volcán.

Los nombres de las muchachas

Que hayamos amado más. 


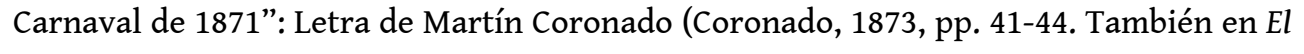
carnaval de 1871, colección de canciones de las comparsas que saldrán este año, Buenos Aires, Imprenta de la Discusión, 1871 y en Almanaque Carnavalesco, por Orion, Buenos Aires, La Tribuna, 1871, pp. 99-101).

Tal vez nos dispensarán

Que hablemos como los blancos

De superior calidad.

No somos negros groseros

Que ni saben saludar,

Sino que somos muy finos

Como pronto lo verá.

Bailemos una polkita,

Una mazurka o un wals

Y verá, niña del alma,

Que nos sabemos menear.

Yo siento que ya la quiero

Y usté no me mira mal

Por eso con sentimiento

Nos vamos a separar.

Adiós! porque ya me quemo

Y ya no puedo aguantar.

¡Adiós, palomita blanca!

¡Hasta el otro carnaval!

6.- "Canción escrita para la Sociedad Dramática-Musical La Africana y cantada en el

Entre nubes de púrpura envuelto,

tras la noche tranquila y callada,

salió el sol de la nueva alborada

derramando torrentes de luz;

yo le vi palpitante más luego

al mirarte no más, negra mía,

esa luz pareciome sombría,

que no hay otra más bella que tú.

CORO

Bravo, negro

Zalamero,

muy bien dices

tu pasión;

ella es lumbre,

pero, pero... 
lumbre sale

del carbón.

En un valle desierto y salvaje

donde solo mi planta ha pisado,

hay, hermosa, una flor que ha llenado

mi existencia de encanto hasta aquí;

es un aroma deleite del alma

por los goces divinos que encierra,

mas no existe una flor en la tierra

que se iguale en aromas a ti.

CORO:

Bravo, negro

Zalamero,

muy bien dices

tu pasión;

huele a flores,

pero, pero...

no te fíes

del olor.

En los bosques del suelo Argentino

yo escuché a la calandria cantora

entonar en la tarde y la aurora

melancólico y dulce cantar;

Me encantó, mas hablaste, morena

y a tu voz se deshizo el encanto,

porque en ella hay la nota de un canto

que no puede olvidarse jamás

CORO

Bravo negro

Zalamero

muy bien dices

tu pasión:

ella canta,

pero, pero...

no es el grillo mal cantor.

Muchas veces, al huir la tormenta

con sus nubes en llanto empapadas,

vi del iris las cintas variadas 
morenita del alma te juro

CORO:

Bravo negro

zalamero,

muy bien dices

tu pasión:

ella es iris,

pero, pero...

ponte anteojos

que es mejor.

CORO

Bravo negro,

zalamero

muy bien dices

tu pasión;

haz el cambio

pero, pero...

agua!, agua!

Qué calor! 206 у 209).

Dicen niña que los negros

No saben enamorar

en tamaño, hermosura y color;

y las vi con amor, pero ahora,

que no hay tinte más bello y más puro

que el que imprime en tu rostro el rubor.

Yo el arroyo sentí murmurando

al correr por la vasta pradera

cuando alegre la fiel primavera

levantaba en su orilla un jardín;

me embriaga, mas hoy, negra mía,

sin dolor, sin afán lo cambiara

por el néctar que guardas avara

en tus labios de fuego y carmín.

7.- “Canción en el carnaval de 1869" (El Lince, no. 5, 13-14/2/1869, pp. 2-3. En 1874 apareció también como canción de una "Sociedad Africana" en el carnaval de Córdoba, en el periódico La carcajada de esa ciudad; Carrizo, 2012. Partes de esta letra también figuran en canciones de 1870 de las comparsas montevideanas Pobres Negros Orientales -compuesta exclusivamente de afrodescendientes- y Republicana; Goldman, 2008, pp. 
Ay! Haga la prueba niña

Veremos cómo le va.

Del África yo he venido.

Las blancas solo por ver

Quiérame niña, que el negro

La sabrá corresponder.

No se asuste de mi cara

Que si es negro su color

Es! Ay! Porque lo ha quemado

El fuego de inmenso amor.

Y así negro y quemado

A mí me amaban también

Pero un blanco vio a mi negra

Y mi negra huyo con él.

Bajo el cielo de mi patria

Una negra amaba yo

Y a la negra tan querida

Un blanco me la robó.

Mi negra he buscado en vano

Pero me arrepiento ya.

Que al ver las blanquitas niñas

Las blancas me gustan más.

Quiérame pues, niña blanca

Que yo adorarla sabré

Yo la llevaré a mi tierra

De esclavo la serviré.

SEGUNDA

$1^{\circ}$

Porteñas de ojos de cielo

Cual la luna majestuosas,

Como las flores hermosas

Nuestros cantos escuchad.

Que aunque somos africanos

De un color bastante oscuro

Mi amita, yo se lo juro

Que sabemos adorar.

CORO

Mira que negro 
417 Ya los morenos

Como un señor.

Cree que las niñas

Van a escucharle

Y después darle

Su corazón.

$4^{\circ}$

Estos días de alegría

CORO

Pobre moreno

Se ha enloquecido

En su atrevido

Y loco afán.

Dadle unas flores

Niñas del alma

Que así se calma

Su delirar.

$5^{\circ}$

CORO

Adiós amitas

Puras y hermosas

Como las rosas

Y su esplendor,

Quisiera que eternos fuesen

En que se goza el alma mía

Entre el bullicio y placer

Y contemplar de una amita

Su mirar puro y sereno.

Pues me gusta aunque moreno

Enamorarme también.

Adiós amitas del alma

Con pesar nos retiramos.

Pues en el pecho llevamos

La chispa de vuestro amor,

Que jamás en esta vida

Hemos sido más dichosos

Que hoy que escuchamos gozosos

Los ecos de vuestra voz 
Nos retiramos

Y triste damos

Ay! Nuestro Adiós.

8.- "El negro José". Cantada en el carnaval de 1871. Es la misma canción que cantaba la comparsa Los Negros, autoría de Rafael Barreda (El carnaval de 1871, colección de canciones de las comparsas que saldrán este año, Buenos Aires, Imprenta de la Discusión, 1871 y en Almanaque Carnavalesco, por Orion, Buenos Aires, La Tribuna, 1871, pp. 98-99. Mencionada entre la lista de canciones cantadas en La Africana, no. 13, 26/2/1871, p. 2).

Si quieren las niñas gustar de los dulces

Que el negro fabrica pá su paladar,

que venga y los saque de su canastillo

que muy calentitos los puede llevar.

Ay! Jesú que durce

que está el alfajó,

y otro durcecito

que traemos mejor,

Vamos niña branca,

Cómpreme algo usted

Que el dulce que traigo

Es pa su mecé

Vamos, niña branca,

no sea Ud. manca

Compre Ud. los durces

Del negro José.

CORO: Ay! Jesú que durce...

9.- "Cosas de Negro". Cantada en el carnaval de 1871 (Almanaque Carnavalesco, por Orion, Buenos Aires, La Tribuna, 1871, pp. 103-104. Mencionada entre la lista de canciones cantadas en La Africana, no. 13, 26/2/1871, p. 2).

Yo soy africanito niñas

El rostro ved, me lo ha quemado el sol

Y vuestro modo de mirar

Me abraza el corazón

Jesús, qué cara de ángel

No veis que buenas mozas

Chis, chis, chis,

Quien fuera esclavo

Ay!! De reinas tan hermosas

Para una porteñita vivo

Para ella sí, solo será mi amor 
Pues son las niñas del país

Más bellas que toda flor.

Nunca digas eso

No seas infeliz,

Mira que si lo cuentas

Se reirán de ti;

Jesús que disparates

Calla moreno ya

A todos causa risa, já, já,

Tanta barbaridad.

10.- "Himno" (1876) (El Carnaval de Buenos Aires, Febrero 27-28-29, 1876. Con pequeñas variantes también en El Carnaval Porteño, Enero 9-10-11, 1877).

Argentinos oíd que ya entona

La Africana su himno triunfal

Porque el mundo feliz hoy augura,

Una vida de gloria inmortal.

Oíd la voz melodiosa del negro,

Que del blanco supera el nivel

Y orgulloso nos muestra sonriendo

En su frente ceñido un laurel

CORO

Somos africanos

De negro color,

Pero muy valientes

En cosas del amor.

Por eso nosotros

Al blanco señor

Le disputaremos

Un ángel de amor.

En el Sud de la América Libre

Hace tiempo nos vemos amados,

Por mujeres divinas que nacen

Para dicha del negro, cuitado.

Si un recuerdo lejano tenemos

De la tierra que nos vio nacer,

Nuestra mente nos dice "sois libres"

Y otra patria bendita tenéis.

CORO: Somos africanos, etc. 
11.- "La Perla africana" (Habanera) (1876) (El Carnaval de Buenos Aires, febrero 27-28-29, 1876).

La amita aquí hemos venilo

Los neglos en pacotilla

A cantale unos coplillas,

Al oilo de su melced,

La amita ilegalesé

Que de amol vamos hablar

Pues somos muy entendilo

En eso de enamola.

CORO

Yo soy Francisco

Yo soy Manuel

Yo soy Antonio

Yo soy José

Yo soy Francisco,

Yo soy Manuel

Vamos amita

Elija usté.

El amol es una cosa

Tan grande y delicá,

Que al milando a las amitas,

Me delito como sá.

Y mas si colespondencia

Llego por fin alcanzá,

Entonces tolo lo olvilo

Pol una amita alelá.

CORO: Yo soy Francisco, etc.

12.- "Mazurka" (1876) (El Carnaval de Buenos Aires, Febrero 27-28-29, 1876).

Niñas ved que la Africana

la ha vuelto a levantar,

ostentando como tema

su bandera de igualdad.

Somos negros pero amantes,

y sabremos conquistar,

el cariño de las bellas

que bien nos quieran amar.

Hace tiempo que los negros, 
soñamos con el amor

de una blanca candorosa,

sensitiva cual la flor.

grande será el galardón

que ofrecemos a las niñas

que nos den su corazón.

un Paraíso y un Edén

el amor de una mujer.

Ella sabe cariñosa

mitigar nuestro dolor,

un beso casto de amor.

Domingo de Carnaval

me vestí de mascarita,

y me fui con mi chinita

en el Prado a pasear

CORO

Como eta Panchita

como eta llorá,

como tan branca

y enamolá.

Vente conmigo, chinita,

vente conmigo a bailá,

a mí me gusta bailá.

arrímese usted, por Dios!

que puede vení el señó.

Yo soy el neglo Antonio

Si nuestra conquista es grande,

Hay un cielo en este mundo

para el mortal que ha obtenido

ella imprime en nuestra frente

13.- "Habanera" (1876) (El Carnaval de Buenos Aires, Febrero 27-28-29, 1876).

ay, los dos bailaremos el tango

CORO: Como eta Panchita, etc

Arrímese usted un poquito,

hay! por Dios, no se arrime Ud. tanto,

CORO: Como eta Panchita, etc.

14.- "El negro Antonio" (1877) (El Carnaval Porteño, Enero 9-10-11, 1877).

Y me plesento á preguntá 
Si los que nacemos libre

Lo amite la socielá

Aunque neglo soy amante

Y á las brancas quiero amá

Como ama mi tío Fanchico

A la nigrita Canabrirá.

CORO

Juá Juá Juá Juá

Mila la amita

Que pletenciones

Los aflicanos

Quieren amá

A la niña branca

Linda y hermosa.

Como la rosa

Nacila acá.

SOLO

No escucha ete neglo

Por Dios amita

Es un tunante

Y un cachafá.

Y un cachafá y un cachafá.

Mila la amita

Que pletenciones

Los aflicanos

Quieren amá

A la niña branca

Linda y hermosa

Como la rosa

Nacida acá.

Lleno de amá siento el pecho

y mi alma huela etá

Cuando pienso que soy neglo

Nacido en el Africá

Si la amita toro eto neglo

Que de Africa han venido acá

A ofrecerles sus simbricios

Y también nuestra amistad. 
601

CORO: Juá Juá, etc.

CORO: Y un cachafá, etc.

Vivan las amitas

Viva el carnaval

Días de esperanza

y felicidad

VOZ 1ra.

En que son los africanos

dichosos ya por demás

pues pueden a las amitas

con libertad enamorar.

Voz 3ra.

Calle el moreno atrevido

se habrá visto cosa igual

primero que el capataz?

CORO

No hay aquí esclavos

ni capataz

Los dos son negros

y nada más.

Por consiguiente

puede callar

que todos juntos

vamos a hablar

VOZ 1ra.

Ante todo quien debe

hablar amitas soy yo

estoy muriendo de amor.

CORO

En ese caso

Todos estamos muriendo

¡Y cómo no!

SOLO: No escucha ete negro, Por Dios amita, etc

15.- "Los tres negros" (1870) (Sociedad Musical 'La Africana'. Carnaval de 1870, pliego suelto conservado en el Instituto de Investigación Musicológica "Carlos Vega", Universidad Católica Argentina. Agradezco a Omar García Brunelli por facilitarme una fotografía).

que quiera hablar el esclavo

que hace tiempo por las blancas 
63

Si en nuestro pechos

ardiente y noble

existe amitas

un corazón.

VOZ 1ra.

Si es que todos los morenos

Sentimos un mismo mal

Un mismo remedio todos

debemos necesitar

CORO: Eso es verdad, eso es verdad.

VOZ 2da.

El remedio que yo creo

Ha de ser muy eficaz

Es que nos traten las niñas

Con mucha amabilidad

CORO: Eso es verdad, eso es verdad.

VOZ 1ra. y 3ra.: Sin dudas que este moreno

CORO: Que este moreno

VOZ 1ra. y 3ra.: Tiene gran capacidad

CORO

Sin dudas que este moreno

Tiene gran capacidad

Pues adivinó el remedio

Que curará nuestro mal

CORO: Eso es verdad, eso es verdad.

VOZ 1ra.

Ahora que cese el canto

Pues mejor será bailar.

VOZ 2da.

Tiene rasgos este negro

De una gran capacidad

CORO: Eso es verdad, eso es verdad.

16.- “Tango" (1870) (Sociedad Musical 'La Africana', cit.)

Por unos ojos del cielo

Y unos labios de coral

Me vuelvo loco, lo digo

Con toda sinceridad.

CORO 
Y aquí que hay tantas

De ojos celestes

Y labios rojos

Como el coral

Bueno es negrito

Que andes con pausa

Que sino... loco

Te volverás

Ya sé que hay muchas hermosas

Blancas como el azahar

Pero qué importa, soy negro

$Y$ no me quieren amar

CORO

Y eso qué importa

Si nuestros rostros

Son por desgracia

Como carbón

Acaso el blanco

Como el moreno

Igual no tiene

El corazón.

Por eso ahora más que nunca

Blanco quisiera ser yo

Pues tal vez alguna blanca

Me entregara así su amor.

CORO

Quiérannos niñas

Que los morenos

Más que los blancos

Amantes son.

Sus corazones

Son el emblema

De la constancia

Y el puro amor.

Nos niegan su amor las blancas

¿Qué hacer? Como el ruiseñor

Cruzar la vida llorando

Las penas del corazón. 
CORO

Esa es la vista

Vivir llorando

Los que son negros

Por el amor

Algunos blancos

Porque son pobres,

Blancos y negros

Por el amor

Adiós en valde es que cante,

Pues jamás lograr podré

Que una blanca como nieve

Me pueda en verdad querer

CORO

Adiós amitas

Que en vuestro cielo

Siempre la aurora

Luzca en paz;

Y que la nube

Del desengaño

No enturbie nunca

Su claridad.

17.- "El esclavo" (romanza) (1870) (Sociedad Musical 'La Africana', cit).

CORO

Negro es mi rostro

Pero tu huella

La sigo blanca

Porque es mi estrella

Creer y sentir.

Un sol ardiente

Bañó mi cuna

Y por fortuna

Me dio servir.

Soy la cimiente

Del pobre esclavo...

Y un nuevo clavo

Me viene a herir

CORO: Negro es mi rostro, etc 
Envidio el aura

Que tus cabellos, Los riza bellos

Con su pasar.

Envidio el dulce

Murmullo leve

Que presta breve

Tu respirar.

CORO: Negro es mi rostro, etc

De mi cadena

No siento el peso

Si escucho el beso

Que sueles dar

Mi pobre pecho

Sufre su herida

Porque mi vida

Solo es pesar!

CORO: Negro es mi rostro, etc

Cuando tu duermes

Tu esclavo vela

La luna riela

Tu blanca sien

Y cuando cruzo

Por tu aposento

Mi pensamiento

Sueña tu bien!

CORO: Negro es mi rostro, etc.

Por qué el esclavo

Cierra los ojos

A los antojos

De su pasión!

Y sufre el yugo

De su destino

Que es peregrino

Del corazón!

CORO

Negro es mi rostro

Pero tu huella 
La sigo blanca

Porque es mi estrella

Creer y sentir.

18.- "Marcha coreada I" (1870) (Sociedad Musical 'La Africana', cit).

CORO

Si es grato reír

Si triste es llorar

Venga la careta

¡Viva el carnaval!

Alegría que alumbras al mundo

Como cruza un meteoro en el cielo,

Esperanza del suelo profundo

Del perdido paraíso recuerdo!

Elevamos a ti los cantares

Con que reímos del mundo falaz

Y volvemos la vela a los mares

Del amor, el misterio, el azar

CORO: Si es grato reír, etc.

La aventura venimos buscando

Engañados tal vez por la fe,

¡Ah! Dichoso quien puede cantando

De una ingrata morir a los pies

Demos campo a la franca alegría

Empinemos la copa hasta el fin

Sin temores gocemos un día

Que quien goza un momento es feliz

CORO

Es tal la alegría

Del mundo falaz

Que para reírnos

Se hizo el carnaval

Venid niñas, venid dad al viento

De la grata alegría la voz

Que al oíros estalla el contento

Y sus cantos os da el corazón

Venid niñas, venid sin enojos

Con los labios cargados de miel

Con el fuego de amor en los ojos 
Con promesa de un mágico Edén

CORO: Es tal la alegría, etc

Cual las aves al rayo primero

De la lumbre dorada del sol

Cual a vista del puerto el viajero

A las bellas cantamos amor.

Seguimos en rápido vuelo

Mariposas que van al pensil

Tal vez genios que van hacia el cielo

Tal vez formas de un sueño feliz

CORO

Si siempre los locos

Dicen la verdad

Sublime locura

Es el carnaval

Oh, déjame seguir la esperanza

Que nos mece en continuo vaivén

Luz que nunca en la vida se alcanza

Y que guía en la vida nos es

Sí, dejadnos creer en un día

A los otros del año no igual

En que pueden con franca alegría

Los que se aman decir la verdad

CORO: Si siempre los locos, etc.

Sí, dejadnos un día tan solo

Que no turbe el orgullo traidor.

Que las nubes del mundo y su dolo

Ni un instante deslumbren el sol

Y busquemos aquélla aventura

Que en amores nos hace soñar

Que entre cantos, risa y locura

Hoy jugamos un juego de azar

CORO

Si todo es mentira

Si todo es afán

Lancemos el grito

Viva el Carnaval.

19.- "Brindis" (1870) (Sociedad Musical 'La Africana', cit). 
La Africana solo aspira

a que un recuerdo alberguéis

de estos instantes que forman

su corona de laurel

CORO

Todos bebamos

Que este moreno

Habla como hombre

De corazón

Si el sentimiento

Puro ha nacido

El sol el alma

No ennegreció

Si estos negros agradaran

Cual lo creen en su ilusión

Fuera néctar de los cielos

Un sorbo de este licor

CORO: Todos bebamos, etc

¡Negros! qué importa si todo

Es de la mano de Dios

La noche tiene la luna

Nosotros el corazón

CORO

Ya nuestro pecho

Va cobijando

El dulce soplo

De inspiración;

Es un perfume

Que la alegría

Robó del cáliz

De alguna flor.

Bebamos, y nuestra vida

Vuele en alas del placer

Mañana será ya tarde

Y qué importa lo de ayer

CORO: Ya nuestro pecho, etc.

20.- "Schotis" (1870) (Sociedad Musical 'La Africana', cit).

De nuestra patria africana 
No estrañamos (sic) el calor

Que hay aquí cada morena

Que nos quema el corazón

En vano son baldes de agua

Para apagar nuestro fuego

Que el agua más nos inflama

Pues, somos carbón los negros

Agua, agua;

Fuego, fuego

Agua a la fragua

Ay de los negros!

(ilegible) tras el día

(ilegible)sterio al amor

Y el negro sigue a su niña

Como las sombras al sol.

Blanca y negro si se juntan

No pierden en su color;

Que aquello que más contrasta

Nos da mayor ilusión.

Fuego y agua

Agua y fuego

Negro con blanca

Blanca con negro.

No hay una cosa más linda

Ni encuentro nada mejor

Que una blanca como inglesa

Con cejas como carbón

Una linda cabellera

Como los rayos del sol

Sobre una frente morena

Que abrasara el ecuador

Agua, agua

Fuego, fuego

Con esas blancas

Se compran negros.

Oh cuan bello es de la aurora

El misterio y confusión

Y las sombras misteriosas 
941

En el ocaso del sol.

Si echamos en una copa

De un licor otro licor

Notaremos cómo embriaga

Esa mezcla de los dos.

Agua, agua;

Fuego, fuego

Agua a la fragua

Ay de los negros!

El pan con pan es sonsera

Agua y vino es lo mejor

Un negro con una blanca

Y junto a la nieve el sol.

Las tristes y alegres notas

Se mezclan en el amor

Y forman una armonía;

Ven, formémosla los dos.

Fuego y agua

Agua y fuego

Negro con blanca

Blanca con negro.

Que viva pues la alegría

Que viva la confusión

Todo en el mundo es mentira

Como es mentira el color.

Antes eran las Marías

Tan negras como el carbón

Hoy las Marías son blancas

por las blancas clamo yo.

Agua, agua

Fuego, fuego

Con esas blancas

Se compran negros.

21.- "Habanera" (1870) (Sociedad Musical 'La Africana', cit).

CORO

Ea, negros! ya es llegada

Nuestra ansiada fiesta anual

Pues cantemos con loca alegría 
979

980

981

982

1003 CORO

1004 Tu eres negro y ellas blancas

1005 La partida no es igual

1006 Mejor es que digamos en coro

1007 ¡Hurra, hurra al carnaval!

1008 1ra. y 3ra VOZ

1009 Porteñas de mi vida

1010 De talle de palmera

1011 Por Dios que una siquiera

1012 Me mire sin rencor

1013 Que tengo el alma grande

1014 Más grande que el desierto

$1015 \mathrm{Y}$ el pecho siempre abierto

1016 Al fuego del amor. 


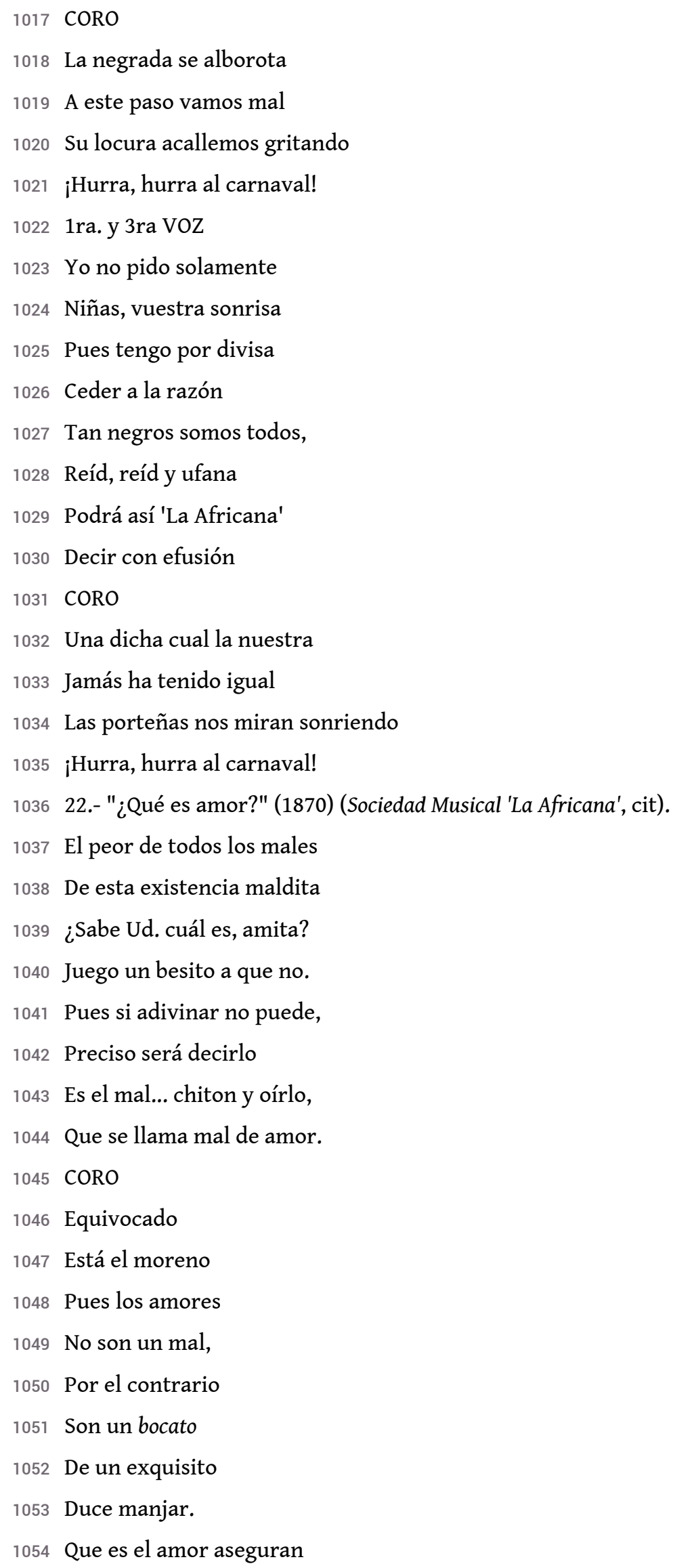


1055

1079 CORO

1080 Eso es bastante,

1081 Ya no queremos

1082 Hoy más lecciones

1083 Sobre el amor

1084 De todos modos

1085 Nadie echarlo

1086 Puede -si- el entra

1087 Al corazón

1088 Adiós niñas, perdonadme

1089 Si hablé mal de los amores,

1090 Pues muy agudos dolores

1091 Por ellos sintiendo estoy;

1092 Ninguna amita me quiere 


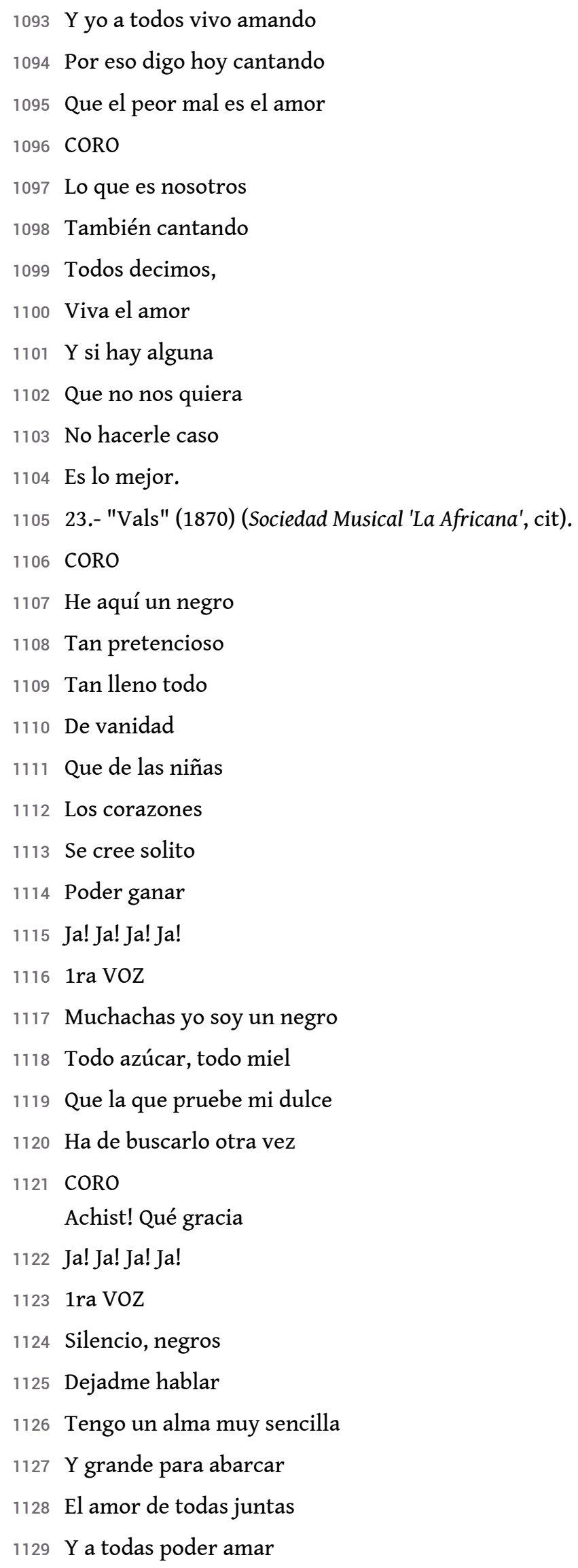




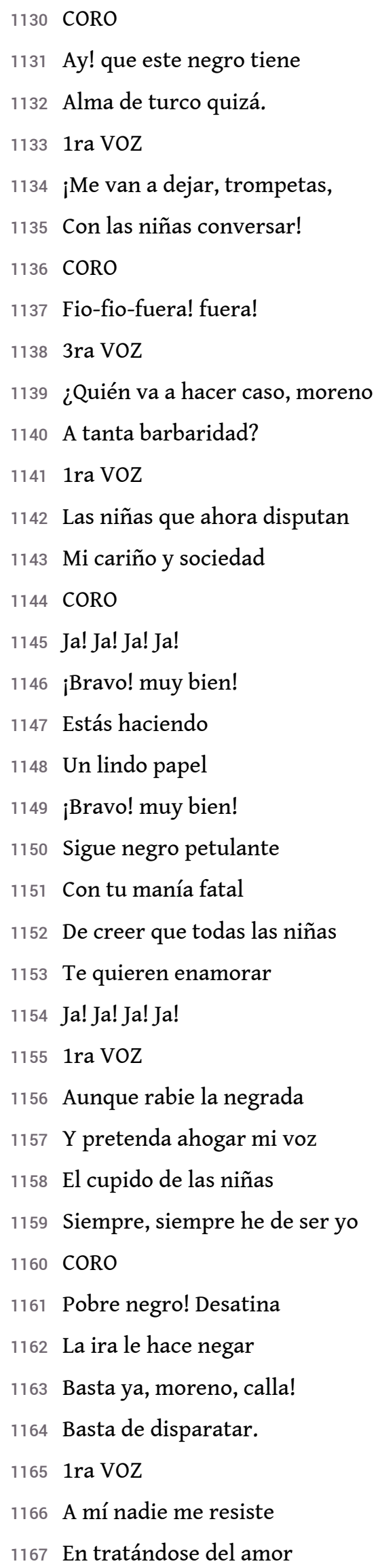




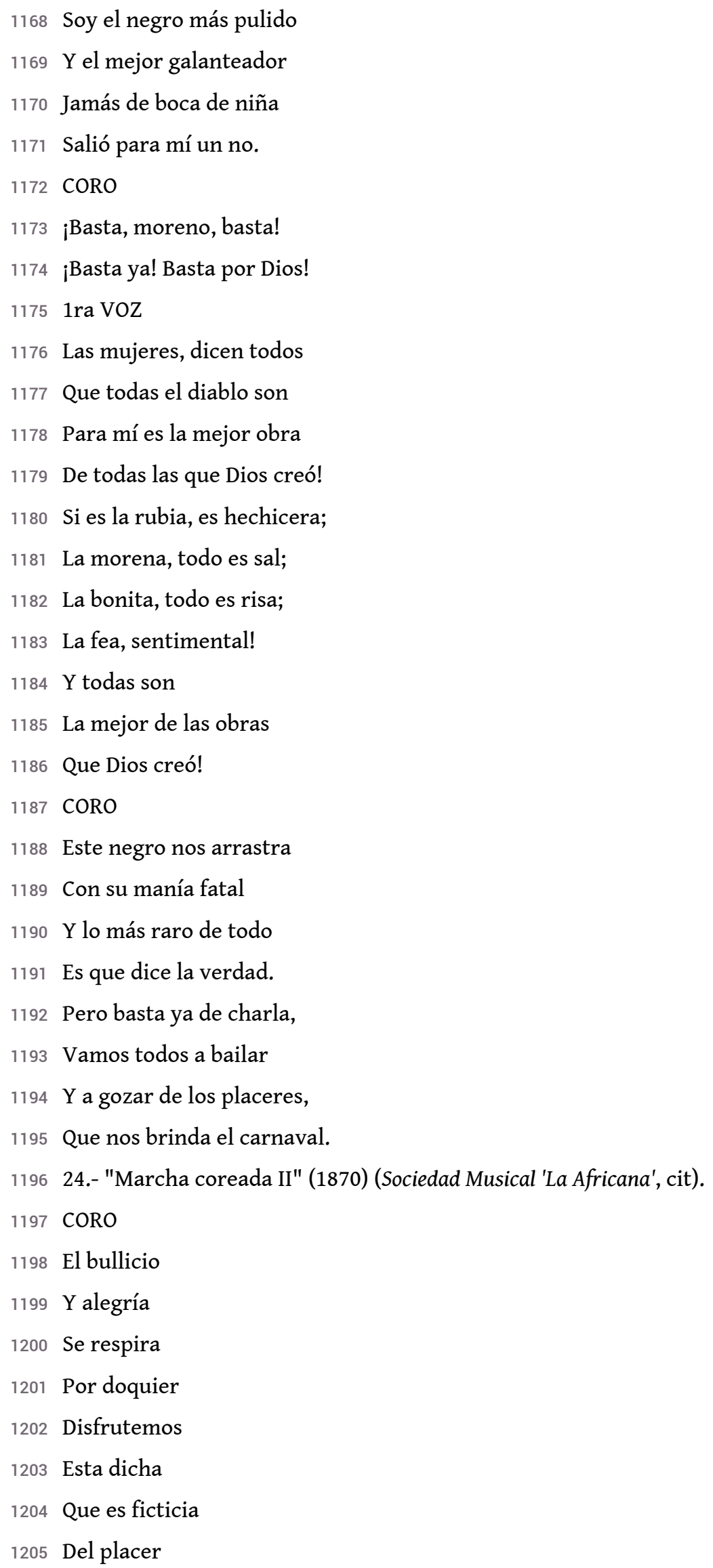


1206

1212 Y olvida en un día

1213 Años de pesar

1214 Venid y gocemos

1215 Sus gratas delicias

1216 Sus dichas postizas

1217 Su dulce reír.

1218 Venid y apuremos

1219 En locas orgías

1220 Mentida alegría

1221 Placeres sin fin.

1222 CORO: El bullicio, etc

1239 25.- "La patria del Africano" (1871) (El carnaval de 1871, colección de canciones de las comparsas que saldrán este año, Buenos Aires, Imprenta de la Discusión, 1871; Almanaque Carnavalesco, por Orion, Buenos Aires, La Tribuna, 1871, p. 97-98).

$12401^{\circ}$

1241 En los bosques sombríos del desierto

1242 Del África, querida de mi alma 
1249

$12583^{\circ}$

26.- "Brindis" este año, Buenos Aires, Imprenta de la Discusión, 1871; Almanaque Carnavalesco, por Orion, Buenos Aires, La Tribuna, 1871, p. 104).

1276 Venid africanos

1277 Alegres brindemos

1278 Las copas llenemos

1279 De hirviente licor. 

Buenos Aires, La Tribuna, 1871, pp. 104-105)

1302 CORO

1310 Ay! brindo yo.

1311 También yo brindo porque Himene

1312 Pronto os regale con su dulzor,

1313 Y que halléis todas buenos esposos

1314 Tan amorosos cual somos nos.

1315 CORO

1316 Por esto brindo 
1317

1318

1319 Muy bien habló;

1320 Muy amorosos

1321 Somos, ay! nos,

1322 Pero ninguna

1323 Nos da su amor.

1324 Amitas mías será, ya, bueno

1325 Que aquí este brindis, tenga ya el fin

1326 Y que apuremos pronto las copas

1327 Y a bailar vamos ¿no creis así?

1328 CORO

1329 Este moreno

1330 No tiene igual!

1331 Que idea tan bella

1332 Irse a bailar

1333 Sí, sí, las copas

1334 Dejemos ya....

1335 Que toquen polka

1336 Que toquen walz.

1337 28.- "Canción 103”" (1871) (El carnaval de 1871, colección de canciones de las comparsas que saldrán este año, Buenos Aires, Imprenta de la Discusión, 1871; Almanaque Carnavalesco, por Orion, Buenos Aires, La Tribuna, 1871, p. 106).

1338 Hay un día en la vida del hombre

1339 En que solo es de gloria padrón

$1340 \mathrm{El}$ acento argentino de un labio

$1341 \mathrm{Y}$ un suspiro profundo de amor.

1342 Ese día se llama en el mundo.

1343 "Juventud, luna eterna de miel"

1344 Y el objeto de nuestros desvelos

1345 Es el ángel llamado mujer.

1346 Es por eso que hoy va la Africana,

1347 Animada por blanca ilusión,

1348 A pedir las preciosas coronas

1349 Del hermoso jardín del amor.

1350 Vengan, pues, esas manos de nieve

1351 A ceñir sin temor nuestra sien,

1352 Que la vida sin risa y amores

1353 Es eterna y pesada vejez. 
1354

(1876) profundo de amor.

1362 29.- "Brindis" (1876) (El Carnaval de Buenos Aires, febrero 27-28-29, 1876).

1363 Cantemos

1364 Bailemos

1365 Brindemos

1366 Sí, si

1367 Bebamos

1368 Alegres,

1369 Gozemos

1370 Placeres,

1371 De amor

1372 Sí, sí, sí.

1373 El cáliz

1374 Llenemos,

1375 Del rico

1376 Licor.

1377 De aroma

1378 Apuremos

1379 (ilegible) febril

1380 (...)

$1381 \mathrm{Y}$ hagan, tin tin

1382 Viva el Madero

1383 Y también el (ilegible)

1384 CORO

1385 Brindemos

1386 Africanos,

1387 Brindemos todos

1388 Por el licor.

$1389 \mathrm{Y}$ a las porteñas

1390 Les brindaremos

1391 Delicias de amor. 


\section{BIBLIOGRAPHY}

Adamovsky, E. (en prensa 1). Los Negros, la primera comparsa de blancos personificando negros del carnaval porteño (1865-1870). Cuadernos de Antropología Social.

Adamovsky, E. (en prensa 2). Blackface minstrelsy en Buenos Aires: las actuaciones de Albert Phillips en 1868 y las visitas de los Christy's Minstrels en 1869, 1871 y 1873 (y una discusión sobre su impacto en la cultura local). Latin American Theatre Review.

Adamovsky, E. (en prensa 3). Comparsas y agrupaciones de negros o africanizantes en el carnaval de Buenos Aires, 1864-1922: Un relevamiento crítico. Avances de CESOR.

Adamovsky, E. (en prensa 4). Disfraces de negro en el carnaval porteño: descripción, tipología e hipótesis sobre sus procedencias (1865-1940). Páginas (UNR).

Andrews, G. R. (2007). Remembering Africa, Inventing Uruguay: Sociedades de Negros in the Montevideo Carnival, 1865 - 1930. Hispanic American Historical Review, 87(4), 693-726.

Armesto, F. (1914). Mitristas y Alsinistas (1874). Buenos Aires: Alsina.

Carrizo, M. (2012). Córdoba morena, 1830-1880. Córdoba, Facultad de Ciencias Económicas de la UNCO.

Cirio, N. P. (2015). Estética de la (in)diferencia: Las canciones de las sociedades carnavalescas afroporteñas de la segunda mitad del siglo XIX de cara al proyecto nacional eurocentrado. Latin American Music Review, 36(2), 170-93.

Chamosa, O. (2003). Lubolos, Tenorios y Moreiras: reforma liberal y cultura popular en el carnaval de Buenos Aires de la segunda mitad del siglo XIX. En H. Sábato y A. Lettieri (Eds.), La vida política en la Argentina del siglo XIX, (pp. 115-135). Buenos Aires: Fondo de Cultura Económica. Chasteen, J. C. (2000). Black Kings, Blackface Carnival and Nineteenth-Century Origins of the Tango. En W. Beezley y L. Curcio-Nagy (Eds.), Latin American Popular Culture: an Introduction, (pp. 43-57). Wilmington: SR Books.

Coronado, M. (1873). Poesías. Buenos Aires: Coni.

De Lucía, D. O. (1999). El carnaval porteño: el proceso de su constitución como campo simbólico (1868-1880). Desmemoria, 23-24, 126-148.

De Lucia, D. O. (2003). La ópera y su aporte a la formación del Carnaval porteño (1800-1880). El Catoblepas, 20, http://nodulo.org/ec/2003/n020p12.htm\#kp60

Geler, L. (2010). Andares negros, caminos blancos: afroporteños, Estado y Nación Argentina a fines del siglo XIX. Rosario: Prohistoria.

Geler, L. (2011). ¿Quién no ha sido negro en su vida? Performances de negritud en el carnaval porteño de fin de siglo (xix-Xx). En P. García Jordán (Ed.), El Estado en América Latina: Recursos e imaginarios, siglos XIX-XXI, (pp. 183-211). Barcelona: Universitat de Barcelona.

Gesualdo, V. (1961). Historia de la música en Argentina, 1536-1961. Tomo III. Buenos Aires: Beta.

Goldman, G. (2008). Lucamba: Herencia africana en el tango, 1870-1890. Montevideo: Perro Andaluz. Lamarque, A. (1871). Ensayos poéticos. Buenos Aires: Coni.

Lane, J. (2005). Blackface Cuba, 1840-1895. Philadelphia: University of Pennsylvania Press.

Lipski, J. M. (2005). A History of Afro-Hispanic Language. Cambridge: Cambridge University Press. 
Lopez, J. A. (1927). Quilmes de antaño. s/l.

Lott, E. (2013). Love \& Theft: Blackface Minstrelsy and the American Working Class. New York: Oxford University Press.

Martin, A. (2008). Folclore en el carnaval de Buenos Aires. Tesis doctoral en Antropología. Universidad de Buenos Aires.

Martín, A. (2015). Candombe, progreso y blanqueamiento forzado en los festejos

del carnaval de Buenos Aires a fines del siglo XIX. En C. Crespo, H. Morel y M. Ondelj (Eds.), La política cultural en debate: Diversidad, performance y patrimonio cultural, (pp. 21-50). Buenos Aires: Ciccus.

Puccia, E. (2000). Historia del carnaval porteño. Buenos Aires: Academia Porteña del Lunfardo.

Sanches, D., Andruchow, M., Costa, M. E. y Cordero, S. (2006). El Carnaval de los "blancos negros. En L. Maronese (Ed.), Buenos Aires negra: identidad y cultura, (pp. 115-144). Buenos Aires: Comisión para la Preservación del Patrimonio Histórico Cultural de la Ciudad de Buenos Aires.

Soler Cañas, L. (1963). Pardos y morenos en el año 80. Revista del Instituto de Investigaciones Históricas Juan Manuel de Rosas, 23, 272-309.

Thelwell, C. (2020). Exporting Jim Crow: Blackface Minstrelsy in South Africa and Beyond. Amherst: University of Massachusetts Press.

Vega, C. (2016). Estudios para los orígenes del tango argentino [en línea]. Buenos Aires: Universidad Católica Argentina/Instituto de Investigación Musicológica “Carlos Vega”. Disp. en http:// bibliotecadigital.uca.edu.ar/repositorio/libros/origenes-tango-argentino-vega.pdf

\section{NOTES}

1. Utilizo los términos "negros" y "afrodescendientes" de manera intercambiable. Adviértase sin embargo que el segundo, que pone el eje en la etnicidad pero no en atributos raciales, es el modo preferido para referir a ellos en ámbitos académicos y en la actualidad, pero no era utilizado en esa época. Por el contrario, los actores de entonces -tanto los percibidos como blancos como los afrodescendientes para autodesignarse- preferían términos que aludían al color de piel, como "negro" o "moreno".

2. La denominación de "falsos negros" o "negros falsificados" se utilizaba en esa época para designarlas, junto con otras como "blancos tiznados" o "negros de hollín". En Montevideo se los denominó también "negros lubolos".

3. La Cartera de Orión, 14/2/1869, p. 3; El Río de la Plata, 6/3/1870, p. 2; La República, 25/2/1870, p. 1; La Prensa, 22/2/1871, p. 2; La Ondina del Plata, no. 9, 27/2/1876, p. 107; La Ondina del Plata, no. 6, 14/2/1877, p. 72; La Nación, 23/2/1879.

4. Los Negros, 25/7/1869, p. 4; De Lucia, 2003.

5. Los Negros, no. 51, 6/3/1870, p. 2. Ver también Armesto, 1914, p. 45.

6. Los Negros, no. 51, 6/3/1870, p. 2.

7. La Tribuna, $4 / 3 / 1879$.

8. La Africana, no. 9, 29/1/1871, p. 3; López, 1927, p. 344.

9. El Río de la Plata, 3/3/1870, p. 2; De Lucía, 2003, López, 1927, p. 344.

10. La Africana, no. $1,20 / 11 / 1870$, p. 4 ; no. $11,12 / 2 / 1871$, p. 3 ; no. $12,19 / 2 / 1871$, p. 4 ; no. 13 , 26/2/1871, p. 2.

11. La Africana, no. $13,26 / 2 / 1871$, p. 2.

12. La Africana, no. $1,20 / 11 / 1870$, p. 4; no. 13, 26/2/1871, p. 2. 
13. La letra de ese brindis está agregada en manuscrito en la p. 76 del original que conserva la Biblioteca Nacional de España.

\section{ABSTRACTS}

The carnival of Buenos Aires in the last third of the 19th century was an arena for the negotiation of ethnic-racial differences, in one of the most multi-ethnic and changing cities of the world. During carnival various enactments that included representations of ethnicities took place, one of the most notable of which was that of white men in blackface. This article undertakes an investigation into the phenomenon of blackface carnival ensembles, beginning with the compilation of the songs of one the first and best known ensambles, La Africana, which is also the one that has left more lyrics registered in archives. On the basis of an exhaustive examination of archives, 29 of their songs are reproduced in this paper, which also allows for an analysis of the main features of La Africana, its possible connections with transnational culture and its enactments of blackness at carnivals.

El carnaval porteño del último tercio del siglo XIX fue una arena para la negociación de las diferencias étnico-raciales, en la que era una de las urbes más multiétnicas y de población cambiante del planeta. Durante el carnaval se realizaban actuaciones que incluían representaciones de etnicidades, una de las más notables de las cuales fue la de los blancos que se disfrazaban de negros. Este trabajo apunta a contribuir a una indagación sobre el fenómeno de las comparsas de falsos negros, documentando las canciones de una de las primeras y más conocidas, La Africana, que es también la que mayor cantidad de letras dejó registradas. Sobre la base de un trabajo exhaustivo de archivo, recuperamos aquí 29 de sus canciones y avanzamos en una descripción de las características de la comparsa, de sus conexiones posibles con expresiones culturales de circulación transnacional y de los sentidos de negritud que pusieron en juego en los carnavales.

\section{INDEX}

Keywords: Carnival, cultural appropriation, Buenos Aires, blackface

Palabras claves: Carnaval, apropiación cultural, Buenos Aires, lackface

\section{AUTHOR}

\section{EZEQUIEL ADAMOVSKY}

Universidad Nacional de San Martín, Universidad de Buenos Aires y Consejo Nacional de Investigaciones Científicas y Técnicas, Argentina.

Correo electrónico: e.adamovsky@gmail.com 